

\section{LIBRARY OF CONGRESS.}

$S$ H 365

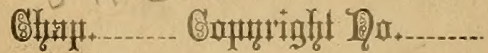
Shelf:A $3 \mathrm{Cl}_{4}$

UNITED STATES OF AMERICA. 


\title{
The Life Histoky, Propagation
}

\author{
AND Protection
}

OF THE

\section{AMERICAN OYSTER}

An Essay Read Before the Georgia Historical Society

DR. A. OEMLER,

MARCH 4TH AND APRIL IST, I889,

In the interest of a bill which is to be introduced in the Georgia Legislature

For the Protection and Development of the Oyster Industry of Georgia. 


\title{
The Life History, Propagation
}

\author{
And Protection
}

OF THE

\section{AMERICAN OYSTER}

An Essay Read Before the Georgia Historical Society

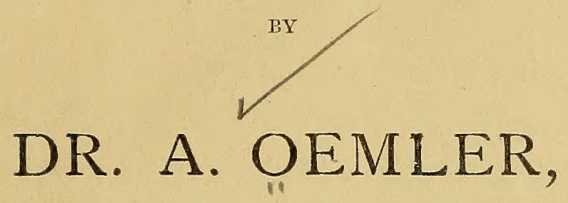

MARCH 4TH AND APRIL IST, I889,

In the interest of a bill which is to be introduced in the Georgia Legislature

For the Protection and Deveiopment of the •

Oyster Industry of Georgia.

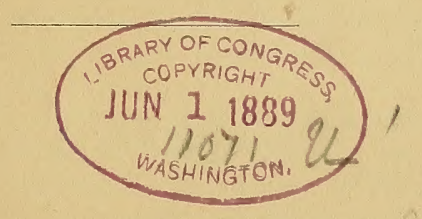

SAVANNAH, GA.:

THE MORINING NEWS PRINT.

1889. 


\section{$S H 365$ . $\mathrm{A}_{3} \mathrm{O}_{4}$}

Copyright, 1839 , by Dr. A. Oemler.

After the reading of the essay Capt. Robert Falligant introduced, and the society unanimously passed the following resolutions:

Resolved, That the Georgia Historical Society has heard with great interest the very remarkable lecture of Dr. Oemler upon oyster culture, and is profoundly impressed with the importance of the subject discussed, and the vast amount of information arrayed by the learned lecturer.

Resolved, That the Society offer its thanks for the able and interesting discussion of the subject, and request a copy of the lecture for file in the archives, and for such future use, as the Society may determine upon. 


\section{THE LIFE HISTORY, PROPAGATION AND PROTECTION OF}

\section{THE AMERICAN OYSTER.}

Exclusive of an intervening coast line of nearly one thousand miles, between Damariscotta, Me., and the Bay of Chaleur, the American oyster is found on the entire eastern shore of the North American continent. It occurs in more or less profusion, covering greater or smaller areas, according to the degree of favorable surroundings, from the Gulf of St. Lawrence to the Gulf of Mexico. That in former times its habitat was an unbroken line from gulf to gulf, is proven by the great heaps of shells near the seaboard, the relics of Indian encampments, and large quantities covering extensive areas of neighboring sea bottom within the limits of that interval. Our own Georgia sea islands bear the same witness to the general use of the oyster as an article of food by the Indians. It is always on the seaboard, or eastern side, nearest, therefore, to the beds, and on the highest parts of the islands, that we find these shells. They lie on the fields so thick as to for m impediments to cultivation, and are so free of soil as to have been burnt into lime on Wilmington Island, for several generations, for building purposes. Pieces of Indian pottery among the shells prove that the Indians partook of them as well in the form of stews as on the half-shell.

The American oyster is known to science as Ostrea Virginiana. To designate a supposed species in the Gulf of St: Lawrence the name of Ostrea Canadensis, and another in York Bay, that O. borealis were given; but they are now held to be mere varieties, produced by differences of environment. With an abundance of food for the animal, and of carbonate of lime in the water for the formation of its shell, and room for its full and free development, its growth will be rapid, the shell thick, regular and more round in form. If crowded together, as in the case of our raccoon oysters, they become long and thin shelled, with very sharp bills, for which reason they are also called razor blades.

Ostrea conchophida is a small species found off the coast of California, and Os. lurida a larger and better one in Shoal Water Bay of Washington Territory.

Apparently in order to maintain a conservative equilibrium among the number of all animated beings on the earth, the Creator, in his all-wise plan of nature, has endowed those of his creatures most beset by numerous enemies, or whose life in its earliest stages is of most doubtful survival, with a comparatively prodigious fecundity. Thus the queen of the white ant lays 60 eggs in a minute, 80,000 in 24 hours, and $40,000,000$ during its 
existence of two years in its perfect state. Thus an aphis, or plant louse, may be the progenitor of $729,000,000$ of descendants in five generations, and there may be twenty such generations in a single season. Were it not for its numerous predatory enemies, every green leaf on the earth would be devoured by aphides, destroying vegetable life and causing the death by starvation, first, of every herbivorous, and then, necessarily, of every carnivorous animal. If every egg evolved from our American oyster survived the first stages of its existence, and the surrounding water contained food enough for the sustenance of the animals, and lime enough for the construction of their shells, every full grown specimen might be the parent of 300,000 bushels of oysters. This quantity would be equivalent to 373,264 cubic feet of shells, or sufficient in the aggregate to block up the mouths of our rivers, causing impediments to commerce and inundations of the interior country. In general, animals do not procreate their species until they have at least nearly attained full growth; but in the case of our American oyster, its survival being so very precarious, nature makes an exception in its favor, and ripe products of generation are put forth within the first year of its life, and when only threefourths of an inch in size. The wisdom of this comparative fruitfulness is demonstrated in individual species of the oyster itself. Thus the European oyster (Os. edulis) is bi-sexual, while our American species is uni-sexual, or every individual specimen is either a male or a female. The eggs of the former are three times as "large as those of the latter, but average only about $1,500,000$ in number. A microscopic lens of 100 diameters will show the egg of the American species to be pear-shaped and $\frac{1}{500}$ inch in size, or 500 in linear contact will be one inch in length. A large specimen may contain a cubic inch of eggs, and the cube of 500 is $125,000,000$. A very liberal allowance of one-half for absence of actual contact, and for ovarian substance, gives us about $60,000,000$ of eggs as the product of a single oyster. But Os. edulis enjoys the very great advantage over Os. Virginiana of having its ova fertilized within the folds of its own mantle, and of its protecting shell; while those of the latter are evolved as soon as mature, and their survival up to an equal starting point with the former depends upon a chance fertilization in the open surrounding water: Carl Möbius, Professor of Zoölogy, at Kiel, Germany, the great authority on the European oyster, has calculated that each oyster that is born in Europe has only one chance in 1,045,000 of reaching maturity. He calculated that only 44 per cent. of the mature European oyster lay eggs each year, nor is the quantity of spawn near the same each year, either in Europe or America. The causes of this unequal fecundity in different seasons are not yet known, but they are supposed to be weather influences and differences in the density of the water. Professor Mobius says: "To 1,000 human beings we count on 6.26 births, and of 1,000 human beings born 554 reach the age of twenty or more years. The productiveness of the oyster is, therefore, $7,000,000$ times larger than that of man; but the capacity to mature is 579,000 times greater in man than in the oyster." His calculations are based upon the fecundity of the European species and upon the possibilities of the German beds, situated near the islands of Sylt, Amrum and Föhr, in a latitude six degrees neare 
the north pole than any habitat of the American species. What ratio of survival we might be able to secure in Georgia, with a better climate and fewer enemies, if we bring the intelligence of man to the assistance of nature, as the Rhode Island and Connecticut oystermen have done, instead of repressing her efforts by the most outrageous and criminal improvidence, is beyond computation.

Fortunately temperature and depth of water are supposed alone to affect the time of spawning; at any rate, each bed will be under the same influences and, therefore, the products of generation of the sexes will be given forth at the same time.

Within from two to four hours after fertilization a tuft of long hairs or cilia appears at the anterior part of the body, by means of which these little creatures row themselves up from the bottom and swim about actively; and they now commence to construct the shell. During this free swimming stage the valves are symmetrical, but do not quite enclose the animal. It is the second period of great danger, for being perfectly defenceless, and sometimes so crowded together, a small fish swimming with open mouth might easily swallow in a few mouthfuls a number equal to a season's survival. The young oysters are also subject to contingencies of weather during this stage of existence. Dr. W. K. Brooks, of the Johns Hopkins University, (the best American authority on the oyster, and the investigator of its life history,) found that a sudden cold wind, or a fall in temperature, during his experiments, killed every embryo in his care. The number destroyed by cold rains and winds must be very great indeed. In addition to its numerous predatory enemies, the oyster must, itself, be considered more or less destructive of its own species; for Prof.J. A. Ryder reported to Prof. Baird, in 1883, he had found, besides numerous eggs, 200 young in the stomach of an adult oyster, which the animal had been guilty of swallowing at a single meal. These young oysters ranged from $\frac{1}{500}$ to $\frac{1}{200}$ of an inch in size, had their shells already developed, and the larger ones had themselves been feeding, inasmuch as food could be seen in their stomachs. We have no means of ascertaining how long a natatory oyster may survive in the open water; but they have been artificially preserved for six days. Its chief aim in life now is to find a resting place and a home. An indispensible condition of its survival is: that during this period it shall find some clean, solid object to which it may attach itself. If unsuccessful in its blind quest, it perishes or is swept out to sea. Mud is the most formidable enemy of the oyster. Even if the water which passes through its gills or lungs is muddy, the little creature dies from asphyxia or suffocation. If, in its search for the homestead, upon which its life depends, it encounters a film of mud of the thickness of a sheet of writing paper, its fine soft organs of locomotion being inadequate to free it from the engulfing medium, its course is run. A large oyster may be deposited upon a muddy bottom and survive, provided the mud be of sufficient consistency to sustain its weight so that its bill may reach high enough above the bottom for the animal to draw clean water through its gills for the purification of its blood, and into its mouth for its support. Having found a clean, solid object, the young oyster proceeds to attach itself by its left valve through the secretion of shelly matter, and soon loses its symmetrical form. 
Henceforth the constantly increasing thickness of shell protects it from all enemies, unless they are able either to perforate or to erush its armor; but during the first six months of its existence the thin, delicate shells, from $\frac{1}{16}$ to 1 inch in diameter, are liable to be torn off by crabs, sheephead, toad fish, or to be bored by drills. The rate of growth depends upon the amount of food and carbonate of lime in the surrounding water, upon the season or temperature, and upon the density or saltiness of the water, the increase in size being more rapid with an admixture of fresh water, owing partly to the additional food the latter contains. While the oyster is strictly a saltwater mollusc, a certain amount of fresh water is not only favorable to its growth, but also improves the quality of its flesh. When heavy winds blow in from the sea, raising the tides and rendering the water colder and more salty, the oysters close their shells and do not feed.

Shell oysters are classed as Extras, Box and Cullens. In our warm latitude they attain the former size in three years on favorable ground; but in the colder climate of the North not until the fourth. The English market demands an oyster the size of a silver dollar, and are taken from the class of "Cullens," from two to three years old, all being eaten raw from the half shell. Up to 1879, Blue Points, from Great South Bay, Long Island, were preferred by English consumers; but in consequence of a falling off in quality, the "Sounds," from Staten Island, and oysters from East River are now supplying "London stock." The number in a barrel varies from 1,200 to 2,000 , averaging the shipper about $\$ 5.00$ net; but they have to be carefully and snugly packed with their deep shell down in order that the liquor may not escape. The total export to England from New York in 1879 amounted to $\$ 316,500$ gold. Old oystermen believe the oyster attains the age of twenty years; but the natural beds along the entire coast are so excessively fished that the old, large specimens of former days of twelve inches or more are rarely found.

The oyster is not exempt from all enemies after the first six months of its existence. The most formidable one, common to the North and South, is the drum fish (Pogonias chromis). By means of large, round molars, with which its pharyngeal and palatine bones are paved, it is able to crush the hard shells of this and other molluses. Nor does the drum swallow all he crushes, seeming to delight in the wanton destruction he causes. That it must sometimes be immense may be inferred from the number captured by seines. Thus, one haul has been known to land 12,250 fish, averaging 33 pounds and aggregating 202 tons 250 pounds. Our common conch and a large ray also crush the shell, while the whelk (Cycotyphus canaliculatus) and the drill (Urosalpinx cinerea) perforate it by means of their file-like tongue. The star fish is so formidable an enemy that legislatures and town corporations have been asked to offer rewards for its capture, and an English law exacts a fine from any fisherman who fails to destroy the animal. They are sometimes so plentiful that it is no uncommon occurrence for an oysterman to dredge up 75 bushels in a day in the eastern part of Long Island Sound. In 1878, after some rougb and gloomy weather, an oyster planter forked up 2,500 by actual count with an eel spear, at Pocasset, Massachusetts, within two days, in water from three to five feet deep. Ernest Ingersoll 
saw a pile of dead star fish, at Warren, R. I., of 1,000 bushels. representing 100,000 of the animals. A single inroad of star fish upon Providence River cost the planters $\$ 150,(0)()$. Northern oystermen were formerly in the habit of tying them up in bundles. of cutting them to pieces and of casting the severed parts back into the sea. But, as these star fish, with several other species of Astride, are capable of propagation by division, they were simply multiplying, instead of destroying, their enemies. Having found a molluse upon which he intends to operate, he pursues a unique mode of burglary. Folding his five rays round it in a firm grasp, the robber proceeds to break in by cracking off the "nib" or "bill." piece by piece, until he has made a sufficient opening. when he protrudes the distensible mouth of his stomach, the whole of the latter following, into the shell. If the molluse is a large one, he draws the pouches, which are packed away in the rays, to his aid, until the animal has turned itself completely inside out. Specimens are frequently dredged up in this condition. In their. turn, many of the star fish embryos find their way into the stomachs of clams and oysters. Prof. Alex. Agassiz estimates the star fish reaches its full growth in fourteen years, and, fortunately for oysters, does not spawn before its sixth or seventh year.

Our raccoon oysters owe their name to the fancied resemblance in shape to the tongue of that animal and not to any supposed use he makes of them as food. In fact, oysters are in no danger of extermination from the rapacity of any quadruped; the danger that menaces them is the covetousnerss of bipeds.

A very interesting feature in the life history of the oyster is the little oyster crab (Pinnotheres ostreum). Being neither capable of defense nor escape, it may readily be understood what an easy prey the little creature would be to every fish, without its harbor of refuge within the shell of the oyster, which it can leave at will. As a matter of fact, the male is very rarely found. What a most wonderful provision of nature for the purpose of securing its continued existence, to endow the female (for she alone inhabits the oyster) with the instinct to avail herself of this sanctuary! She is a true messmate and not a parasite, as might be supposed. In fact, as it were from gratitude for the protection afforded, she lecomes a caterer for the oyster, the minute scraps which fall from her tiny claws serving as food for the mollusc.

Upon an examination of the valves. or the two shells of an oyster, one is seen to be more concave than the other. The former is the left, the latter the right valve. Near the centre of each is a light brown or purple spot, more rough than the common surface. These spots were the points of attachment of the strong abductor muscle, which passes through the animal from side to side and must either be detached or cut before the oyster can be opened, its functions being to keep the shell closed. With us this muscle is commonly called the heart; at the North the eye of the oyster. In point of fact, the oyster has no eye. If the animal wishes to open its bill, the muscle relaxes and the valves are forced open by the distending elasticity of the hinge ligament, which is compressed while the valves are closed.

Very briefly stated, the general anatomy of the oyster is the following: Except near the ligament, the entire body is enclosed in iwo flaps, the mantle, from the outer surface of which the sub- 
stance is secreted to form the shell. The inner edges of the mouth are provided with a double row of tentacles, while beneath it are four very finely ridged folds, which form the gills or breathing apparatus of the animal. These gill-folds or plates extend near the hinge, or anterior part of the oyster, where they are superceded by four other folds, the lips, and here is the opening leading into the body, or the mouth of the mollusc. All the food the oyster gets has to be brought from the open bill to this part of the aninal, and this is effected by the cilia, with which the gill plates are supplied, too small to be seen by the naked eye. These all lash the water in one direction, creating a steady current over the gills, and whatever food the water contains passes in to the mouth cavity. Just anterior to the dark spot near the centre of the oyster, which is the abductor muscle, we find the heart, enclosed in the pericardium and consisting of two auricles and one ventricle. The stomach is an irregular cavity of considerable size, surrounded by the lobules of the liver, from which ducts lead into it. The ready digestibility of raw oysters, which renders them so well adapted to convalescents and dyspeptics, is attributable to the liver and its secretions. Folds of the intestines lead back and forth, ending near the abductor muscle.

Through microscopic examinations of the contents of the stomach, the food of the oyster has been ascertained to consist chiefly of cliatoms, minute free swimming vegetable organisms enclosed in silicious cases, most genera of which are contained in salt water. Several additional species and similar microscopic plants called desmids, however, are contained in fresh water. About 88 per cent. of the food consists of these and fragments of other alge, and 12 per cent. of the embryos of molluses and of other low forms of animal life. The flavor and color of oysters depend upon the diatomaceous flora of the water from which they derive their food.

A sudden and marked change in the weather will not only retard or check the spawning of the oyster, but also affects its quality. The free floating diatomaceous food of the oyster, like all other vegetable organisms, is attracted by the light of the sun and, therefore, rises to the surface, beyond the reach of the bivalve in clear, dry weather; hence in cloudy or rainy weather, the surrounding water being more nutritive, oysters improve in quality.

When taken from water of great density, or which is very salty, oysters remain poor until very late in the season. If removed, however, into water more fresh than that in which they were born, they lose a portion of their salinity and also actually a very slight part of nutritive ingredients by dyalysis, or osmose, and absorb the fresher water. Oystermen avail themselves of this process in fattening, floating, plumping or drinking their oysters, as it is variously designated. They become improved in taste and in plump appearance; but, as a matter of fact, are merely bloated into a similitude of fatness. If the water is warm, a single tide may suffice. At Franklin City, Md, one planter actually resorts to warming the water during cold weather to from $60^{\circ}$ to $65^{\circ}$ by steam pipes under his plumping floats. 


\section{PROPAGATION.}

The yield of oysters from the growth of natural beds having become inadequate, three methods of increasing the supply have been adopted successfully in Europe and America, Oyster planting, oyster farming and the artificial fertilization of the eggs with the rearing of the young oysters in specially prepared ponds connecting with the sea. The first merely enlarges the quantity and improves quality by accelerating growth, while the two latter actually increase the supply by augmenting production.

As long ago as early in the seventh century, a Roman Knight, Sergius Orata, undertook oyster farming and the planting of oysters, obtained elsewhere from natural beds, in Lake Lucrin: and Pliny informs us that he became very rich.

The first attempt at planting oysters in this country seems to have been made in old Shrewsbury township, N. J., about seventyfive year's ago, and the next occurred in Harlem River, with seed oysters procured from City Island, East River, N. Y. Formerly, large quantities of Chesapeake oysters were planted in northern waters, 2,178,750 bushels having been shipped in 1879 for that purpose. The New Haven fleet alone, employed in that year in that transport, consisted of eighteen schooners. Since that recent day, the intelligence of Connecticut oystermen has made her not only independent, but she now exports large quantities of seed oysters to other states. This transfer of southern oysters to northern bottoms might have been made more profitable, if they could have been put down in June instead of very early in the spring; and this could have been possible by the employment of steam, but for the very peculiar fact: that any concussion while in bulk between decks is destructive to these molluscs, and that they would have been affected by the throb of the engine. Even the chopping of wood on deck was prohibited on board the schooners. Heavy thunderstorms and the firing of guns have been known to destroy them.

The first requisite of successful oyster culture is a proper bottom. Neither soft mud nor pure sand will answer; but a mixture of the two, covered with a layer of shells, forms the best planting ground. To prepare a bottom otherwise too soft, Connecticut oyster planters sometimes use 200 tons of sand to the acre, but a current is essential to success. The improvement of oysters, when transferred from their natural beds to planting ground, is not always and necessarily owing to any amelioration in their surroundings, or to a larger relative amount of food contained in the water: but, probably, to the more regular distribution, whereby a larger quantity of nutriment may reach each animal. It is also attributable to the more uniform size and age of the planted stock; for a large number of small oysters attached to the larger will impede development and prevent the fattening of the latter. For seed in Lastern waters, oysters one, two and three years old are used, according to the time the planter intends them to remain on the bottom and the trade for which they are designed. When put down at one year old, they will be fit for opening at three; and one-third of them will class as "box" and two-thirds as "cullens." Twelve bushels planted on about thirty feet square will take up, if left for four years, at the rate of seventy-five bushels, when they 
will be three to four inches long; and a bushel will hold from 150 to 200. From 600 to 1,000 bushels are planted to the acre. About half a million bushels of Chesapeake oysters were planted in the waters of Jelaware in 1879 , at a cost to the planter of less than 2.) cents a bushel: and taken up after four months, they sold for over $s()$ cents per bushel. which may be considered a loss to Maryland of $8.275 .0(10$. The profits of a single Fair Haven firm between 15.5 and 1856 was $\$ 25,000$ per annum. About 1576, an oyster planter netted 1.000 per cent. on his outlay on oysters put down two years before.

In general, transplanting young oysters in water fresher than that wherein they were born will promote rapid growth. At Jamaica and in Hemstead Bay, Long Island, the water being shallow and warm, with an influx of fresh water, the planters take up oysters for market in the fall which had been put down in the spring, with a certainty that they will have attained at least double their size. Were it otherwise, the shallower portions of this exceptionally fine planting ground would be useless, in consequence of the destruction of the oysters by ice in winter.

Because of the high rate of freight (about $\$ 10$ per barrel) across the continent, those shipped from the East to be planted as seed in the Pacific are very small, some being mere blisters, a barrel holding from 3,000 to 5,000. For this purpose, oysters from Newark Bay and the North River are preferred, as they seem to stand the journey better.

When the supply of oysters imported for immediate consumption exceeds the demand, the surplus is bedded, both in England and California. proving the facility with which they may be transported long distunces and the hardiness of the animal. But a curious fact is that such oysters placed in the Pacific will not survive more than six months, nor will the species removed from the Atlantic spawn in the Pacific. That they may become inured to cold by exposure is demonstrated by the fact that our raccoon oyster will survive a lower degree than single oysters from beneath low-water mark. Professor Lockwood describes the systematic practice by which oysters were formerly trained to hardihood as follows:

"Before the railroad days, our oyster growers used early in the fall to canvass the villages on the Hudson River for orders, to be filled just before the river should be closed by ice. The meaning of this is, that these men committed themselves to supply oyster's in the shell, with the guarantee that the bivalres thus supplied should not die before their time came. The oysteris were actually kept alive during the greater part of the long winter. The fat bivalves were handled with some care, and were spread on the cellar floor, the round or lower side down, so as not to allow the liquor to escape.

"That such a life required a great change of capacity or habit in the bivalves is evident, and it needed a training, yes, an education, ere the oyster attained to such ability.

"And this is the way it was done: Beginning early in the fall, the cultivator of the oyster took up the fat bivalves from their bed, where he had planted them, and laid them a little higher up on the shore, so that for a short time each day they were exposed out of the water. After a few days of this exposure by the re- 
treating tide, they were moved a little higher still on the shore line, which gave them a little longer exposure to the air at each low tide. And this process was continued, each remove resulting in a longer exposure. And with what results? Two very curious ones: Inurement to exposure and the inculcation of a provident habit of making preparations for the same. What! providence in an oyster? Yes, when he's educated. When accustomed to this treatment, ere the tide retires, the oyster takes a' good, hard drink and retains the same until the tide returns. Once, while waiting for the stage at a country hostelry, we overheard the following between two rustic practitioners at the bar: 'Come, Swill, let's take a drink.' 'Well, I don't know. Ain't dry myself. Hows'ever, guess I will take a drink, for fear I might get dry.' With better philosophy on their side, these educated oysters, twice in twentyfour hours, took their precautionary drink."

"The French method of oyster training is much more laborious. The adult bivalves are carefully spread out in the water and periodical lessons are given to each one individually. Each oyster, on this occasion, receives a tap with a small iron instrument. This causes the bivalves to close tightly. Finally the last day comes with its last premonitary tap. Its education thus finished, it takes passage with its fellow-graduates for Paris. As a result of its education, it knows how to keep its mouth shut when it enters society."

* "The history of the oyster industry of Rhode Island furnishes an interesting illustration of the value of an intelligent system of planting."

"All bottoms between high-water mark and the ship channel are public property, to be controlled and administered by the State in such a way as to secure the greatest good to the greatest number of its citizens.

"In 1865 laws were passed allowing the leasing to private citizens for a term of years at an annual rental of $\$ 10$ per acre, of any bottoms which are covered by water at low tide and are not within any harbor line, to be used as a private oyster fishery, for the planting and cultivation of oysters, whether these lands contain natural beds or not, and efficient laws were enacted for the protection of private rights.

"The effect of this measure has been good in every respect. The revenue of the State has been greatly increased; and it is stated that the rentals of the beds will, in time, pay all the expenses of the State government.

"The price of oysters has decreased, and the supply has become so abundant that only one-tenth is needed for the home market, and nine-tenths of the annual supply are sold outside the State.

"In 1865 oysters sold for $\$ 1.75$ per" solid gallon; in 1878 the price was $\$ 1.15$ to $\$ 1.10$, and in 1879 it had fallen to 90 cents.

"In 1865 the product of the State was 71,894 bushels, while in 1879 it was 660,500 bushels. The area which was used for planting in 1879 was only 962 acres. yet this area paid $\$ 6,582.90$ into the State Treasury; it employed a capital of over $\$ 1,000,000$ : it paid $\$ 125,000$ in wages to the people of the State; it furnished the market with 660,500 bushels of oysters, with $\$ 680,500$ to the producers, and it gave support to 2,400 persons.

*Report of the Oyster Comnaission of the State of Maryland, 1884. 
"In 1857 , the revenue from oyster rents was only 830 In 18(i2). there were collected $\$ 82 ; 1863,860 ; 1864,861$. Then came the present law, with private rights and private planting, and the net proceeds of oyster rents to the State, at once advancerl as follows: $18(j), 8737.72:. 1866 \%, 86(i 1.27 ; 1867,81,568.50) ; 1868.81 .814 .40)$ : $18(69,81,949.15 ; 1870, \$ 1,527.65 ; 1871,82,186 .(63 ; 1872,82,772.95 ;$ $1873, \$ 4,483.85 ; 1874, \$ 4997.05 ; 1875,85,276.00 ; 1876,85,300.00):$ $1877, \$ 6,045.25 ; 1878, \$ 6,582.90$."

In fourteen years, it had increased to $\$ 6,5,2-107$ fold, or 10,790 per cent.

"It is, moreover, an admitted fact that assignments of oyster" ground were continually taking place in 1879 at a bonus of from $\$ 75$ to $\$ 200$ an acre."

"Tp to 188?, the Rhode Island grounds had been used only for planting, and most of the seed oysters were purchased from other States; yet the planted oysters sold for three or four times the cost of the seed: and it is doubtful whether there is any farming land in the Tnited States which yielded as great a profit as the 1,100 acres which had been used that year for oyster planting in Rhode Island."

The Oyster Commissioners of Maryland calculated, in their report for 1884 , that, if all the area of their State which is proper for oyster planting were used in this way, and were no more profitable than the oyster grounds of Rhode Island, it would yield to the planters the inconceivable sum of two thousand millions of dollars. All this, notwithstanding the natural beds of Rhorle Island had been so depleted by excessive tonging that they were of little value, only being able to supply less than one-eighth the seed used for planting. But, fortunately for the oyster industry of Rhode Island, her legislators were wise enough to enact a law which has encouraged private effort, enormously increased the supply of cheaper food, and reduced taxation.

\section{OYSTER FARMING.}

It has been shown that oyster planting has been successful; 'but oyster farming is capable of being made much more profitable. If a dollar saved is a dollar made, then the oyster farmer may not only be considered the grower, but the quasi creator of his crop. Grain uncommitted to the soil is not wasted, for it may be made into bread; but if the oyster farmer fails to assist nature, the seed of the oyster that might yield a bountiful harvest perishes and is lost to the world. I submit a bunch of oysters, which probably would not have been in existence, if my son had not deposited the shell a year ago upon which they have affixed themselves.

The principal operation then of oyster farming consists in supplying that sime qua non of the young oyster's survival: clean, solid objects, called "cultch" or spat collectors, for their attachment.

The methods invented by Sergius Orata in the time of Augustus have been followed for centuries by oyster farmers at Lake Fusaro, near Cape Misene, in Italy, where bundles of twigs have been found invariably efficacious as spat collectors.

The natural beds in France were giving out in 1858, when M. Coste made elaborate and costly experiments in oyster culture in 
the Bay of St. Brieuc in the Department Côtes du Nord, opposite the English Channel Island of Jersey, under authority of Napoleon III and at the expense of the Imperial Government. Owing to several unforeseen contingencies, as, for instance, a disastrous storm, which demolished his arrangements and destroyed a portion of his adult oysters, he failed to realize the splendid results he anticipated. He fully demonstrated, however, the practicability of his methods, when he forwarded a bundle of fagots to the Emperor, not occupying any more space in the water than a sheaf of wheat, upon which no less than 20,000 young oysters had attached themselves. Soon afterwards two government furms of about 500 acres each, of exhausted territory, were established; and in $186316,000,000$ of oysters were taken in six tides from one-half the area. Land was then ceded to individuals, and one area of 492 acres was stocked in a few years with oysters valued at $\$ 8,000,000$. Five years previously this was unproductive territory. Since then the French have been very successful. At Arcachon the number of oyster parks increased from 724 in 1871 to 1,706 in 1874 . The following table from the report of $M$. Brocchi to the Minister of Marine shows the increase in ten years in the basin of Arcachon alone:

\begin{tabular}{|c|c|}
\hline Year. & $\begin{array}{c}\text { Number of Oysters } \\
\text { Exported. }\end{array}$ \\
\hline 1871. & . $\quad 4,897,500$ \\
\hline $1872 \ldots$ & $10,796,740$ \\
\hline $1873 .$. & $25,711,750$ \\
\hline $1874 .$. & . $\quad 42,542,650$ \\
\hline 1875. & . $112,715,233$ \\
\hline 1876. & $196,885,450$ \\
\hline $1877 \ldots$ & $202,392,225$ \\
\hline $1878 .$. & $176,500,225$ \\
\hline 1879. & $160,197,275$ \\
\hline $1880 .$. & $195,477,357$ \\
\hline
\end{tabular}

Value in Francs. $268,332.50$ $537,515.00$ $1,159,397.00$ $1,745,050.00$ $2,817,630.00$ $3,941,309.00$ $4,456,288.00$ $4,426,500.63$ $3,944,241.88$ $4,254,465.64$

This is an increase in ten years of 1,585 per cent. in the value of oysters, while the people had an accession of 3,890 per cent. in the number of oysters cousumed. The French method consists substantially in suspending concavo-convex tile in the water during the spawning season, with the former surface down. These are about 18 inches to 2 feet long and 6 to 8 inches wide, like a drain tile cut longitudinally in two. To facilitate the removal of the oysters with a knife without breaking the tile, so that they may be used the next season, they receive two coatings of lime, or one of cement and one of lime. The young oysters seem to attach themselves in rising for they are nearly always on the concave side. Lient. Winslow suspended tile of this description in the Big Anemessex River and counted 348 young oysters on a single one.

The first attempt at oyster farming in the United States was made at City Island, Westchester County, N. I., about fifty years ago by Fordham; and the East River is at present the scene of the most careful and scientific system of oyster cultine in this country. H. C. Rowe, of New Haven, who controlled 1,500 acres in 1883 in Long Island Sound, was the first to venture oyster 
farming at a depth of forty feet. At such a distance from the surface the oysters are not apt to be distured by the turmoil of storms.

When the East River oystermen first attempted to becorne auxilliaries of nature by providing solid objects, for the attuchment of the young oysters, they scattered oyster shells over the bottom, ignorant of the fact that they had to be clean. They put them down so far in advance of the spawning season that they got no set, because the shells had become muddy. Learning wisdom by experience they now resort to shelling during the spawning season, the most propitious time being from July 5th to July 15 th for Connecticut, with such success that they export their 'ieed oysters not only to neighboring States, but abroad and to California, whereas only a few years ago they were compelled to import all their seed oysters from the Chesapeake, 515,000 bushels being the quantity in 1879 . One firm put down 250,000 bushels of shells in 1883 , and another shipped sixty car-loads with $15,000,000$ of seed oysters, five years ago, to be planted in the Pacific. The oystermen were well aware of the fact that there could be no survival of young oysters unless they provided them with something to fasten to, even if the waters were loaded with spawn.

A few years, ago it was accepted by oyster culturists as a truism that masses of spat drifted back and forth with every tide anywhere within a mile or two of a natural oyster bed, and all that was requisite was to place something on the bottom to catch a full set. We have seen how sensitive to injury Dr. Brooks proved the young oyster to be, and within from twenty-four to forty-eight hours after fertilization it should have become attached. Later experience has demonstrated the advisability of placing the spat collectors within twenty rods of a natural bed containing a sufficiency of mature oysters. The more reliable method, and that adopted by all the progressive oyster farmers, is to distribute on the previously prepared bottom twenty-five bushels of adult oysters, or "spawners," as evenly as possible to the acre; and then later, and exactly at the proper time, to scatter from 250 to 500 bushels of shells or pebbles upon the same area. A set having occurred, the oysters may be left undisturbed, unless infested by enemies, until wanted for seed or consumption; but, if a plentiful one, the bottom should be worked over with a wide meshed dredge to bring up only the larger bunches, which are then broken apart and bedded, as every oyster farmer reserves an allotment of his ground for planting, or to be sold as seed oysters.

On the best ground 500 bushels of shells are scattered upon an acre, and in exceptional cases as many as five bushels of oysters have been gathered from one of shells; but as a rule the oyster farmers of Connecticut consider one bushel procured of the former from one of the latter a fair return.

When large shells are used as spat collectors, their surfaces are frequently so thickly covered with young oysters that they become crowded and acquire an objectionable shape. To avoid this possibility, some of the Connecticut oyster farmers now use pebbles instead of shells. When the bottom is too soft for spat collectors to be placed immediately upon it, upright bushes may be inserted in the mud. On the Paquonock River, near Groton, Conn., a bush four inches in diameter at the but had collected twenty-five bushels, seven of which at eighteen months were large enough for market. 
Private oyster farming under the wise laws of Connecticut had only been practiced three years, when a writer in the New Haven Pailadium wrote as follows: "Fifty thousand acres of entirely barren ground, covered 30, 40 and 50 feet deep by the waters of Long Island Sound have been made into productive oyster beds and have multiplied by a hundred fold the production of native oysters. 'l'en years ago, tens of thousands of bushels of oysters were imported from New York, New Jersey and Rhode Island, and now hundreds of thousands of bushels are yearly exported to these States and to Massachusetts. Millions of dollars are now invested in the industry, thousands of men and women are employed, millions of bushels are in growing crops and hundreds of thousands of dollars yearly come into the State as proceeds of exported oysters. The oyster cultivators have paid more than $\$ 5,0,000$ to the towns and to the State for ground to cultivate, and pay a yearly tax to a large amount."

Connecticut sells as much of her off shore territory in fee simple to any male resident as he can cultivate at $\$ 1.10$ per acre and it is subsequently assessed for taxes the same as upland, $\$ 40$ per acre being the highest valuation by the State. The taxes of 1886-87 amounted to $\$ 7,087.75$. To secure, survey, prepare and shell these grounds in deep water costs about $\$ \pm 0$ per acre and it is not deemed profitable for any one to take up less than fifty acres. The eighth report of the Shell Fish Commissioners of Connecticut shows that up to October 31,1888 , the total area granted and now held by cultivators is $78,167.56$ acres. The number of steamers owned by the oyster farmers of the State is 66, one of them having the carrying capacity of 4,500 bushels. I quate from the above report: "One Connecticut firm last year shipped 10,000 barrels of seed oysters to Liverpool and London for planting on English beds-and they expect to ship a larger quartity the coming year. The foreign trade, however, does not compare with the domestic trade. This is continually expanding. wherever facilities of transportation open the way."

*Prof. J. A. Ryder, of the Tnited States Fish Commission, mentioned in 1883 that a younger brother of the firm of Smith Bros., of New Haven, had put his mite of $\$ 500$ into the work and that he had the year following declined the offer of $\$ 3,000$ in hard cash by the firm for his venture, with thanks. My inquiry about the sequel to this transaction results in the information that it netted $\$ 3,000$ after the second year, and $\$ 2,000$ more from the sale of the remaining large oysters at the end of the third, or $\$ 5,000$ in three J'ars, which is 1,000 per cent. for the period from the capital in. visted. The shells had been placed upon the area owned by another, and the latter had received one-half as his share of the profits, or $\$ 2,500$ for the use or rent of the ground, which a few yiars before was considered worthless and had never previously produced a mouthful of food, but the bottom was, of course, of exceptional quality for the purpose, and the crop had fortunately escaped the ravages of starfish.

The highest price paid at private sale for oyster ground in Connecticut, as far as I have been able to learn, was $\$ 300$ per acre. The State of New York sells her off shore unoccupied land at any

Rearing Oysters from Artificially Fertilized Eggs, together with Notes on Pond Culture.-United Stutes Fish Commissirn, 1883. 
figure over $\$ 1$ per acre. So far it has gone for about \$1.2.), and in the bays at from $\$ 3$ to $\$ 5$. The highest lid for bare land, owned by the state, was 820 per acre. As a private transaction $\$ 300$ has has been paid for absolutely bare ground, and for bottom which had more or less material upon it, but sold as cleared ground, sales have been made of single acres of this submerged land at 5500. An expert oyster culturist from City Island, X. Y., now present in the audience, assures me he has recently worked on oyster ground in Long Island Sound still more valuable.

Such are the astonishing capabilities of oyster farming. Here are thousands of acres, heretofore utterly barren, thrown open by wise legislation to private enterprise, becoming productive to the wonderful extent of 2,500 bushels of food material to the acre, and enhanced in value in three years from total worthl wness to $\$ 500$ per acre.

\section{ARTIFICIAL IMPREGNATION.}

In reference to the very interesting subject of artilicial impregnation of the spawn and the rearing of the young oysters in ponds connecting with the sea, I can merely mention that it has been accomplished in Europe and in America. Financially it has been a success in France alone, nor are oysters yet scarce enough in our waters to warrant the trouble of artificial fertilization and the expense of excavating the breeding ponds. An idea of French achievement may be formed from the fact that 800 young have been counted on one-fifth, and 2,000 on a whole tile of oysters, thus born in breeding pans and committed to the ponds for attachment.

\section{PROTECTION.}

Five years ago, the Legislature of Maryland made an appropriation from her oyster fund of $\$ 80,000$ to build two fast guard steamers, and the fleet now consists of these and thirteen schooners and sloops. In salaries alone to her oyster police force she pays $\$ 50,000$ annually, and her protected oyster iudustry supports 55,000 people. That of every coast State, from Virginia to Massachusetts, maintains thousands of families, supplies in the aggregate cheap food to millions of inhabitants, benefits every transportation company from the Atlantic to the Pacific, and. bringing an influx of money into each, promotes the general welfare.

There can certainly be no reason why our Empire State should not be placed in the same category of progress, or why her oystermen should not be permitted to apply their intelligence to the advancement of her prosperity.

Having shown the economic importance of the oyster industry elsewhere, I shall submit to you valid reasous for its protection in Georgia.

As my sons have been engaged in the business of shipping oyster's for years, and, as I am living nearer to what, only a few years ago, were the best and most extensive oyster grounds in our waters, I have been better situated to note the rapid depletion of 
the beds and the outrageously improvident manner of fishing them than any man in Georgia. Knowing, thercfore, perhaps better than any other, that without the agis of legislative protection the oyster industry of the State is doomed, I felt longer inaction on my part would partake of dereliction of duty.

As a delegate from Chatham County to the Agricultural Convention at Marietta in 188:3, I first met Dr. H. H. Carey, the Fish Commissioner of Georgia. He then consulted me in regard to the necessity of protecting and encouraging the oyster interests of the State, and has done so frequently since, notably, during a visit to my home on Wilmington Island about eighteen nonths ago: Prompted thus by my. own sense of duty, by Dr. Carey's wishes, and hy my desire to increase the supply, I have carefully investigated the subject, during the last six years, in order that I might qualify myself to prepare a bill appropriate to our circumstances. I am confident, if the bill I have framed becomes the law, it will promote the general welfare hy increasing the supply of cheap food, by benefiting the entire trade, by advancing the prosperity of the $400 \mathrm{men}$ and women who tong and open oysters in Chatham County alone, and by bringing money into the State.

It has, however, been recently amended. Since the adjournment of the Legislature I have renewed my acquaintance of forty years ago with the delegate from Glymn County, to whom I had been advised to send it for introduction. $\mathrm{H}_{3}$ is now in full accord with me, and will introduce and support the bill to the best of his ability. As I have been instrumental, though indirectly, in placing $\mathrm{Mr}$. Postell in a position where he has been misrepresented, in justice to him I will take this occasion to state the reasons he declined to introduce it were: (1) The bill having originated in Chatham he felt suspicious because neither of her delegates seemed inclined to assume the responsibility, and (2) he desired to ascertain whether his constituents would approve the measure. This he has now done, but in order to meet the views of the people of the lower counties, where the beds are still productive and valuable, I have agreed to several alterations and a new clause, neither of which, however, interfere with the chief objects of my original bill.

As amended, briefly stated, it is as follows:

Section 1. It shall not be lawful to pick or gather oysters with any implement from beds opposite the marshes of this State from April 15th to September 1st, nor from one hour after sunset of Saturday to one hour before sunrise of the succeeding Monday, nor during any right, except at the knoll in Savannah River.

SEc. 2. All culling shall be done over the beds, except on the knoll at the mouth of Savannah River.

SEc. 3. It shall not be lawful to gather planted oysters without the consent of the owner.

SEc. 4 . When a creek, not over 130 feet wide at its mouth, runs up into the land, all the oysters therein shall belong to the owner or owners of the land, as if they had been bedded.

SEc. 5. It shall not be lawful to use any other implement than oyster tongs, except in water over twenty feet deep or more, at low water, and with the approval of the Oyster Inspector.

SEc. 6 . The penalties for violating the abovesections to be a fine from \$25 to $\$ 200$, or confinement in jail from three months to two years. 
SEC T. The County Commissioners shall appoint three expert appraisers, of which the Oyster Inspector shall be one, except when he is himself an applicant, to examine any ground applied for and to place an estimate upon it, opposite any of the public marshes of this State, and upon their report the County Commissioner's shall lease five acres for a term of ten years to any male resident of full age; but the latter shall plant 100) bushels of oysters or scatter 100 bushels of shells to every 10() yards of planting ground, and he shall keep it staked and marked.

SEc. \&. (Incorporated by Messrs. Goodyear \& Kay, of Brunswick, for Glynn County and stated in full.)

That any person or corporation owning lands fronting on tide waters of this State shall have the exclusive right to the oyster privilege fronting the land aforesaid to the distance of 120) feet below low water mark and the right to lease or sell such oyster privilege upon placing boards along such front, as provided in Section 7 of this Act; and shall be entitled to all the protection afforded by this Act to parties leasing such privilege on public lands of this State.

SEc. 9. Provides for a license on boats 18 feet or less of $\$ 3$; on boats over 18 feet $\$ 5$; and on sailing vessels of $\$ 1$ for every ton of capacity; but every such vessel is entitled to a boat for every five tons without a license.

SEc. 10. Every licensed boat or vessel shall have the number plainly painted on the starboard gunwale.

SEc. 11. The penalty for using a boat, \&c., not licensed, not less than $\$ 50$ nor more than $\$ 200$, or confinement in jail, not less than six months nor more than one year.

SEc. 12. Provides for the manner of procedure in case of violalations of this Act.

SEC. 13. The oyster inspectors and constables shall have authority to arrest any one found in the act of violating this Act.

SEc. 14. The penalty for resisting an officer making arrest from $\$ 50$ to $\$ 100$, or confinement not less than six months nor more than two years.

SEc. 15. The coast of Georgia to be divided into two oyster districts: the counties of Chatham, Bryan and Liberty forming the first, and the counties of McIntosh, Glynn and Camden the second.

SEC. 16. An oyster inspector for each district to be appointed by the Governor from the district where he is to serve.

SEc. 17. When the fund accruing from rents, licenses, \&c., exceeds $\$ 1,250$, the excess to be appropriated to the school fund of the county in which they had been collected.

SEc. 18. It shall be the duty of the inspectors to guard their respective districts, to arrest violators of the law, to keep a record of licenses, and to report quarterly.

SEc. 19. Penalty for removing or defacing oyster marks, from $\$ 20$ to $\$ 100$, or confinement from one to six months.

SEc. 20. The Act shall go into effect on September 1st, next ensuing after its passage.

SEC. 21. Repeals all laws in conflict with this Act.

Knowing such a law would inure to their benefit, and anticipating: therefore, their cordial coöperation. I requested the principal dealers to meet me in conference with the members of the 
Legislature, in hopes of taking harmonious action; and I visited the city three times expressly for that purpose. The bill had been previously submitted to them for inspection, and on one occasion a single one presented himself. Immediately after these abortive conferences, an excitement and opposition was aroused among the oystermen at Thunderbolt by misrepresentations that my bill contained a property qualification for all oystering of $\$ 20,000$, during which subscriptions were solicited to a fund for defeating the bill, and threats of personal violence against myself were made in case the bill became the law.

In corroboration of all the former facts I have an affidavit of three intelligent oystermen from City Island, Westchester County, N. Y., the birthplace and present theatre of the most systematic and scientific oyster culture in the United States, who were oystering at Thunderbolt and who actively participated in it, but who after an examination of the bill cordially approve it. One of them assures me, when it becomes the law, he will remove to Georgia in order to enjoy its privileges, because he is satisfied he could then make more money here from oyster culture than in the State of New York. In fact, in order to lose no time, he had bargained with a resident to plant oysters before his departure in the spring in copartnership on the leased ground of the latter, if the bill had passed.

Its opponents have asserted that the oysters on our coast are in no need of protection, inasmuch as the beds are not being exhausted, and that thousands of them are being formed every year. Every oysterman knows this is false; but as their prospective extinction is the chief argument of the advocates of protection, I shall submit at some length a few data and a selection from over forty recorded cases of exhaustion of oyster ground, illustrative of the fact that extermination is the inevitable result of excessive fishing in every part of the world.

Whereas my sons shipped 1,546 barrels of shell oysters to Philadelphia three years ago, the season following they were only able to procure 881 barrels for New York and Philadelphia with nearly double the number of tongers. One other shipper and themselves sent about 20,000 gallons to the North last year, when the latter made bi-weekly shipments. This season they can only make weekly consignments, although they employ a much larger force, for want of oysters. Exclusive of a few beds near private landings, the raccoon oysters are already practically exterminated in Chatham and Bryan Counties.

Local or general causes may influence seasonal variations in the quantity of spat attachment. Last year's freshets not only killed large numbers of oysters, but also either affected the well being of the remainder, so as to prevent them from putting forth the products of generation, or hindered the attachment of the spat. The large quantity of sedimentary matter always brought down in freshet water probably coated every object in our waters, which otherwise could have served as a spat collector. Certain it is that very few oysters of the spawning season of 1888 can be found in Chatham County, and consequently there will be a more than usual scarcity of large oysters two years hence.

Thus has providence and improvidence combined towards a depletion of the oyster beds the past season. 
[From the Report of E. G. Blackford, Oyster Commissioner of New York for 1887.]

1. "The natural growth beds of Rhode Island and Comnecticut are practically extinct, and even the great beds of Maryland and Tirginia are being rapidly exhausted. In fact, although in earlier times oysters were found in large quantities in the waters of New York and New England, the natural beds north of the ('hesapeake ar puctically worthless, save as murseries for seed. There is no doulst that the oyster interests of the State have suffered greatly. many of the natural beds have been entirely obliterated."

\section{[New York Report of 1885.]}

2. "As might be expected, this greedy and persistent working of the oyster territory has had a marked effect in diminishing the oyster areas, and in many places tracts that formerly were flourishing beds of uative oysters have by this means been completely ravished of their inhabitants and have ceased to be beds."

3. "The natural growth beds have been almost incessantly and unscrupulously drawn upon for their products, until now it is probably impossible to find a piece of natural-growth oyster ground within the limits of our State waters, which in productiveness, and especially in the size of the oysters, is not very much below what it was only a few years ago."

[Report of Oyster Commissioners of Maryland, 1884.]

4. "No one who is familiar" with the history of the orster beds of other parts of the world can be surprised at the deterioration of our own beds. Everywhere, in France, in England, in Germany. in Canada, history tells the same story. In all waters where oysters are found at all they are usually found in ahundance, and in all these places the residents supposed that their natural beds were inexhaustible, until they suddenly found that they were exhansted. The immense area covered by our own beds has enabled them to withstand the attacks of the oystermen for a much longer time; but all who are familiar with the subject have loug been aware that our present system can have only one result-extermination."

5. "The improvidence of the people of the United States in lealing with their oysters, so long as they were abundant, has been almost beyond belief."

6. "It is impossible to state whether these beds occupy the place of the beds which were exterminated a century ago: but it is probable that most of the old beds were in shallow water. The hay must have contained oysters to furnish spat; and as no new beds have grown up in shallow water, we are forcel to conclude that, even when spawn is present, a period of a bundred years is not enough to restore a bed which has been completely destroyed."

Favored Georgia! A century is not enough to restore a bed on the most exteusive and most excellent oyster territory cn earth: and here thousands of new ones, forsooth, are forming every year.

7. "Even if our natural beds could be restored and placed as they were twenty years ago, this would only delay for a few years their final exhaustion; for the demand is now far beyond the natural productive powers of our waters, and it is growing greater every day." 
[Ernest Ingersoll's Oyster Industry of the United States, 1880.]

8. "As the best stocked and most productive beds in Europe were quickly destroyed by unrestricted dredging, so may the hitherto seemingly exhaustles; beds of the Chesapeake Bay be depleted, if the present rate of dredging is continued."

Is a matter of fact, the Oyster Commissioners of Maryland reported four years afterwards that during the preceding three years the natural beds of the State had been depleted at the rate of $3 !)$ per cent.

[Report of E. G. Blackford, of New York, 1887.]

9. "A good instance of this deterioration is found in the famous Saddle Rock beds (area 639 acres) near Great Neck, L. I. Years ago, this bed produced large quantities of marketable oysters of excellent quality. The record of my recent investigation of this bed shows: "Dredged seventy-five yards, found a roller skate, bottles, pasteboard, refuse, eight (8) large oysters and one peck of small seed.

[Lieut. Francis Winslow (U.S. N.) Report on the Oysters of James River, Virginia, and of Tangier and Pocomoke Sounds.]

10. "An estimation of the effect of excessive fishing may be formed by examining its results upon such beds in England and France as have records upon the subject. The most instructive of these are the records of the production of the beds of Cancale Bay, which extend over a period of sixty-eight years-from 1800 to 1868 . The beds in the bay comprise an area of about 150 acres. and from 1800 to 1816 produced from 400,000 to 2,400,000 a year. This, however, was the period of the Napoleonic wars, and the fishing was much disturbed by the presence of the English cruisers. During this time the beds became so thickly stocked that the oysters were in some places a yard thick. After the close of the war, the fishing improved, and the oysters were removed in larger and increasing numbers until 1843. From 1823 to 1848 , it is supposed that the dredgers were living upon the oysters accumulated during the period of inforced rest from 1800 to 1816 . In 1817 the number of oysters produced was 5,600,000, and until 1843 there was a constant increase, the number taken in the latter year being $70,000,000$. In 1848 it was $60,000,000$, thence forward there was a constant decrease. From 1850 to 1856 the decrease was from $50,000,000$ to $18,000,000$, supposed to be the effect of over-dredging. From 1859 to 1868 the decrease was from $16,000,000$ to $1,079,000$, the oysters having almost entirely disappeared from the beds. In 1870 there was a complete wreck of the bottom, which could only be remedied by a total prohibition of the fisheries for several years."

12. "From the beds of the districts of Rochefort, Marrennes and Island of Oleron, on the west coast of France, there were taken in 1853 to $185410,000,000$ and in 1854-5.5 15,000,000. On account of exhaustive fishing, in 1863-64 only 400,000 could be obtained."

13. "According to the testimony of Mr. Webber, Mayor of Fal mouth, England, about 700 men, working 300 boats were em ployed in a profitable oyster fishery in the neighborhood of $\mathrm{Fa}$ mouth until 1866 , when the old laws enforcing a 'close time' we' 
repealed, under the impression that owing to the great productive powers of the oyster it would be impossible to remove a sufficient number to prevent the restocking of the beds. Since $186(i)$ the beds have become so impoverished from excessive and continual fishiug that in 1876 only forty men and forty boats could find employment; and small as the number is. they could not take more than 60 or 100 oysters a day, while formerly in the same time a boat could take from 10,000 to $12,000 . "$

14. "According to the statement of Mr. Messum, an oyster dealer and secretary of an oyster company at Emsworth. England, made before the commission for the investigation of oyster fisheries in May, 1876, there were in the harbor of Emsworth, between the years 1840 and 1850 ), so many oysters that one man in five (5) hours could take from 24,000 to $32,(1)(3)$. In consequence of overíishing, in 1858 scarcely ten vessels could find loads: and in $186 s$ a dredger in five hours could not find more than twenty (20) oysters."

15. "Ingersoll states that in the early days of our history it was not uncommon for a man to rake up a sleigh load of oysters through the ice in a single afternoon at Shediac, New Brunswick. Twenty-five or thirty year's ago, these bea's yielded 1,000 barrels a year: and in 1880 two (2) persons gained a scanty livirg upon them and obtained between them about 200 bushels a year."

16. "In 1634 William Wood, in a work on New England. speaks of a great oyster bank in the Charles River, near Boston, and another in the Mystic River, each of such size as to obstruct navigation. The oysters were the long, sleuder 'coon oysters.' Of their size and form he says: "They be great ones in form of a shoe horn: some be a foot long. These breed on certain banks that are bare every spring tide. This fish, without shell, is so big that it must admit of a division before you can well get it into your mouth.' The oyster beds in these two rivers are spoken of by many of the early writers; but they are now gone so completely that there is not a tradition to mark the place where in 1634, according to Wood, 'the oyster bankes do barre out the bigger ships.'

17. "In Mr. Coste's report for 1858 he states that out of twentythree natural beds, which formerly constituted a great source of wealth, eighteen had been completely destroyed, while the remaining beds had been so impoverished that they no longer yielded enough oysters for planting. In another locality, where thirteen valuable beds formerly furnished employment for 200 vessels and 1,400 men for six months in each year, and yielded an annual harvest valued at $\$ 60,000$ to $\$ 80,000$, only three beds remained. and these were so depleted that twenty boats could in a few days carry away all the oysters.

18. "On December 3, 1883, Lieut. Francis Winslow wrote: "The oyster fishery of the State of Connecticut is one of the few instances of recuperation on recort. I know of many destroyed oyster fisheries, and I know of a few that have been rebuilt: and I find one cause common to all failures, and as common to all sucresses. In the first instance, the fishery has been common property, its preservation everybody's business-that is, nobody's - and consequently, it has not been preserved. In the second instance. the fishery has been conducted and owned by persons singly or 
together as private property; it has been this, that or the other man's business to see to its preservation, that is, its preservation has been somebody's business instead of nobody's, and ronsequently, it has been preserved."

In 1876 Prof. Möbius, the celebrated German authority, pul)lished the following prophecy:

"In North America the oysters are so fine and so cheap that they are eaten daily by all classes. Hence they are now, and have been for a long time, a real means of subsistence for the people. This enviable fact is no argument against the injurious effect of continuous and severe fishing. As the number of consumer's increase in America, the price will also surely advance; and then there will arise a desire to fish the beds more severely than hitherto; and if they do not accept in time the unfortunate experience of the oyster culturists of Europe, they will surely find their oyster beds impoverished through their own neglect."

As yet I have heard no argument against the bill by any of its opponents. Such expressions by two of them, that "they want no oyster laws," and by another "that he is opposed to the bill, because, if it became a law, it would make the oystermen too d-d independent," do not deserve consideration.

I have been, however, personally notified by a third, that if I attempted to interfere with his selling oysters in July and Angust, or with what is called "free trade in oysters," he intended to "kill" the bill. Now, oysters are still spawning during these months, and I certainly did not expect to encounter a being endowed by the Creator with a modicum of reasoning power, particularly when he derives a livelihood from oysters, whose intelligence could be so consumed by greed, as to deny it were better to leave them to emit their millions of ova in their native element than to have them digested in the stomachs of the people of Macon and Atlanta, who, deceived by the milk white appearance of the products of generation, swallow pregnant oysters for fat ones. As far as I have been able to learn, there does not exist a law for the protection of oysters of natural growth, which does not enact a "close time." In France, in England, in Canada, in Naine, in Massachusetts, in New York, in Virginia, in Delaware, in Maryland and in Texas, it ends September 1st. In Schleswig Holstein, Germany, in Maryland for dredging, it is October 1st. In New York it is September 1st and October 1st. In Treland it is September 1st, October 1st and November 1st. In Rhode Island it is September 15th and November 1st, in New Jersey it is September 1st and October 1st, all in different localities, and in Thames River, Conn., it is November 1 st.

In their report for 1884, the Oyster Commissioner's of Maryland recommend an extension of the close time to October 1st, and express the belief that it would be beneficial to prolong it to December 1 st.

There is not a single white or colored working oysterman in Georgia who does not approve the clause, and many of the dealers personally desire the close time to extend to October 1 st or November 1st. My sons can never make a shipment before the middle of November, in consequence of the inferior quality of the oysters previous to that time. The first this season was made November 28 th. 
The colonists having become alarmed at the diminution of the supply. the Legislature of New York passed the first oyster law ever enacted in America, as early as 1715, as follows: "That from and after the publication of this Act it shall not be lawful for any person or persons whatsoever (native free Indians only excepted) from and after the first day of May, until the first day of September, annually, to gather, rake, take up or bring to the market, any oysters whatsoever, under the penalty of twenty shillings for every offence, to be recovered before any of His Majesty's Justices of the Peace, who are herelyy authorized and required to hear and finally"dletermine the same; one-half thereof to him, her or them, that shall bring the same to effect. and the other half to the poor of the place where the offence shall be committed.

"And * * * That it shall not be lawful for any Negro, Indian or Mulatto slave to sell any oysters in the city of New York at any time whatsoever, upou the penalty of twenty shillings for every offence, to be paid by the master or mistress of such slave or slaves; to be recovered and applied as aforesaid. This Act to be [in] force from the publication hereof, during the term of five years, and no longer."

Four years later (1719) the colony of New Jersey found it necessary to enact a similar law.

"Whereas, It is found by daily experience that the oyster beds within this Province are wasted and destroyed by strangers and others at unseasonable times of the year, the preservation of which will tend to the great benefit of the poor people and others inhabiting this Province, Be it, therefore, enacted," \&c., \&c. It also provided a close time to September 1 st.

The New York law of 1715 was limited in its effect to five year's. During the ten years succeeding the date of its expiration the same license prevailed in New York that still exists in Georgia to-day, and then came the protective law of 1730. The colonial records contain a note in connection with this law, explaining its necessity, as follows:

"There was an Act of this kind passed in this Province, during" the continuance whereof the oysters encreased to that degree that the city of New York was constantly supplied in the proper season at easie rates; but since the expiration of it, the people being under $n$ o restraint, the banks are almost destroyed. To preserve what is left, and to procure an increase, is the design of this Act, which will be greatly to the advantage of this city, if it be duly observed."

We have here, ladies and gentlemen, an ancient declaration of the necessity, and historical testimony of the efficacy of a law which is vastly more essential for Georgia now, since steam transportation has so greatly increased the demand.

Is it preposterous - am I too progressive in asking the Georgia Legislature to enact a law in this age of advancing civilization which two Northern Provinces had the wisdom, with less exigency. to pass in the first year of the reign of our King George I. 1 4 years ago, or 61 years before the Declaration of Iudependence?

But there is another atrocity in this greed for trade in oysters. Unless in the spawning state, they are so watery in July and August that it requires two and a half bushels, or more, to open a gallon, whereas later one bushel will yield a gallon of opened 
oysters; yet the dealer pays to the poor oysterman, who has to tong two and a half fold the quantity, and to his wife, who has to open them, the same price per gallon, and they are without remedy. Furthermore, there is the loss of one and a half bushels of food material!

While it can only concern the oyster gatherers themselves, (and they generally appreciate its necessity), I gather from the published interviews that one of the opponents objects to the culling clause. The Oyster Commissioners of Maryland attribute the depletion of their beds principally to violations of their culling laws. Such a provision is contained in every law in the United States for the protection of oysters of natural growth, where oyster planting and oyster farming are not extensively carried on. The operation of culling consists in separating all the oysters the tonger wishes to use from those too small for marketable purposes, from the dead shells, and from any other refuse brought up by the tongs. Sometimes the shells are covered with young oysters a few months old. The proper manner is to return at once these young oysters and shells to the beds whence they had been taken, instead of carrying them off, as at present, to be lost and destroyed; and the culling clause provides for this. The penalty for a violation of the culling law in Maryland is a fine of $\$ 300$, or imprisonment for three years. It has been shown that a bed is on its way to extermination, unless there remain upon it at the rate of fifteen young to ten mature oysters. It is, of course, doomed, when the bivalves of every stage, and even the shells, which are our sole spat collectors, are removed. The undisturbed accumulations of centuries have elevated these beds above the general level of the bottom, otherwise the shells upon them would become so coated with mud as to unfit them for spat attachment. In consequence of the fact that the least deposit takes place upon elevations; the French claires, or artificial breeding ponds, are elevated in the middle for the deposit of the oysters, and are provided with marginal ditches in which alone the sediment accumulates. It is evident that, when these elevations in our waters have been reduced by the continued removal of the shells, the deposit of mud will be general and our beds be obliterated.

The reports of the Oyster Commission of Maryland for 1880 and 1884 contain the following references to the importance of culling on the beds: "The reasons for the small number of young oysters we believe to be, in part, the scarcity of mature oysters to furnish spawn, in part to the wanton destruction of great numbers of very young oysters through the violation of culling laws, and in part the absence of enough clean shells on the beds to furnish attachment for the spat. The destruction of young oysters at the packing houses is trifling, however, compared with that which results from violations of the culling laws."

"When we recollect how important it is that the young oysters should soon find solid bodies to fasten themselves to, it will be seen that the danger of exterminating a valuable bed by overdredging would be much less, if the empty shells were replaced upon the beds."

Man has long passed that stage of his existence, when he had to rely upon the uncultivated products of the field, and of the forest. for food; and now he has learnt how to increase his means of 
subsistence by developing the productiveness of land under water. to the depth of forty feet or more; other States having shown us to what astonishing extent the food supply may be augmented by cultivating this heretofore barren territory. It is well known that there is a connection between the number of marriages and births and the price of corn; that prosperity and population depend upon the fertility of the soil. The average width of land sulject to the fertilizing effects of the inundations of the Nile was only 5 ? miles; but its productiveness was so great that Herodotus informs us, Egypt contained twenty thousand cities in the reign of Amasis. Open up our submerged territory to the operation of personal effort, or private enterprise, and it can be made capable of excelling the productiveness of the Nile valley, and that of the oyster grounds of Rhode Island or Connecticut; simply for the reason of the greater propitiousness of our climate, and because our oysters enjoy a superior immunity from predatory enemies; and the lease clause was framed with that object chiefly in view. If the most fertile agricultural domain on the globe were turned over to public gleaning, like the oyster grounds, what would be the chances for progressive or intensive farming? Witness the felling of noble pecan trees in Texas, the growth perhaps of a century. the more conveniently to obtain a single and final crop of nuts. as a case parallel to the atrociously improvident use of our oyster beds. I submit a bunch of oysters, taken from a pile that were being opened. Of the forty-four of which it consists, about ten are large enough to be marketable, and thirty-four would have been cast aside to die and to be lost. Large numbers are daily destroyed in this manner. Sometimes entire bunches are thus thrown upon the shell heap.

In making the distinction between the conditions of the three kingdoms of nature, Linnreus said: "A stone grows, plants grow and live, animals grow, live and feel." Though of a low order. - these are God's animated creatures, and their wanton waste is morally and economically nothing less than sinful. Now, if every oysterman conld have. his own private, protected, oyster ground. these rejected small oysters might be planted and saved to life, to profit and to future usefulness.

In reference to this loss of small oysters, the report of the Oystel. Commission of Maryland, of 1884, says in the chapter "on the means which are necessary to arrest the destruction of our natural beds": "One explanarion which has been urged to account for the destruction of our oyster beds, is the wanton destruction of young: oysters. Upon the piles of shells which are thrown out from the packing houses, great numbers of young shells can often be found. They are of course dead, and as they are too small to be of auy use, their destruction is a clear loss to our people." "This difficulty will disappear with the growth of the planting industry: for small oysters will then be valuable as seed, and they will pass into the hands of the planters, instead of going to the packing houses." "The true remedy, therefore, is the encouragement of planting." "The question arises, whether the destruction, by the packers, of immature oysters should not be prohibited by law, and your commissioners, therefore, recommend that if any dealer in oysters for food shall have in his possession any oysters so small that a bushel measure will contain more than 300 , he shall be liable to a fine of $\$ 1$ for each bushel." 
The oyster law now in force in Georgia gives every property owner on the salts the privilege to plant oysters opposite his taxable land to the distance of 500 yards and 120 feet beyond low water mark, and the proprietorship of all the oysters in any creek running up into his land not over 120 feet wide at its mouth. Very few land owners have a frontage of 500 yards fit for oyster planting. In many cases the wash of sand from the taxable laud either renders the bottom unsuitable, or even destroys the oysters that may have previously existed. As a matter of fact, the most extensive sea island property owner of the State for this reason can not avail himself of the privilege. Under these provisions of the law I am already entitled to the riparian rights of my entire frontage, it being less than 500 yards, and to the oysters in a creek admirably adapted to the purposes of oyster culture to the distance of 2. miles, and no new legislation can increase my oyster privileges as an owner of taxable land. My esteemed friend, your first vice-president, Col. Screven, is an island neighbor, our lands adjoining, and knows these to be facts. The development of the oyster industry will of course increase the value of real estate on tide water and, with a single exception, I hold the signature of approval of my bill of every such land owner, to whom I had applied, and he only hesitated, because at that time he desired to secure greater privileges than my bill provided for.

It very fortunately so happens for the position I have taken in this matter that I own under the present law more oyster ground than any other man in Chatham County, hence, if every public bed in our waters were obliterated, my sons would be able to command comparatively the largest supply.

As population increases, does it not become the duty of every man, when possible, to protect and save the sources of food? Therefore, when the problem is presented to the legislator, the question arises: How will he best increase his popularity and advance his political aspirations, by arraying himself on the side of those who would save an important source for the welfare of the multitude, or by supporting those who would ruthlessly destroy it, to satisfy present personal greed?

But I am informed, it is difficult to effect the passage of any bill in the Georgia. Legislature, if its supporters have to "butt" against any opposition. What legislative, or other reform, has ever been achieved, without having had to encounter, and to vanquish, opposition? What chances would there have been for the reformation itself, if my ancestors' kinsman, Martin Luther, had refrained from "butting" against the mighty power that had burnt his predecessor at the stake? But is it not a serious reflection upon the intelligence of the Legislature, to believe it possible that a bill so plainly promotive of the public welfare could be defeated by an opposition born of the greed of a few opponents, who lack the intelligence to appreciate the fact that a protected and developed industry must necessarily inure to their own ultimate benefit?

I have only learnt within a day or two what amount the little State of Rhode Island will derive this year from the rents of her comparatively limited oyster territory. The wise legislative encouragement of private enterprise in oyster farming has developed the industry to such an extent and advanced the prosperity of her 
oystermen so greatly, that the revenue contributed by them has increased from $\$ 61$ to over $\$ 11,000$, which is 180 fold, or at the rate of over 18,033 per cent.

The same results will follow the same means, under the application of equal intelligence; and my object is simply to open the path for similar benefits to the community, and for as great, or greater, prosperity to our oystermen, in proportion to their superior advantages.

The question, who is most entitled to countenance and support, he that is laboring for this consummation, or they who would frustrate it, I confidently refer to the intelligence of yourselves and of my fellow-citizens generally. 


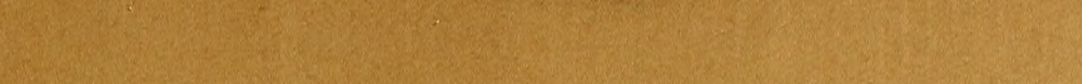
S.

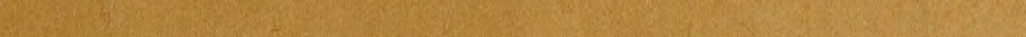

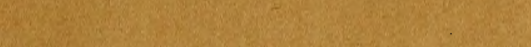

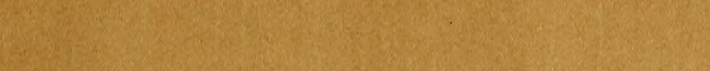

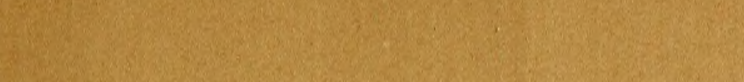

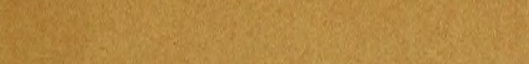

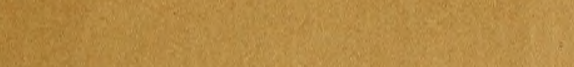
2. (6)

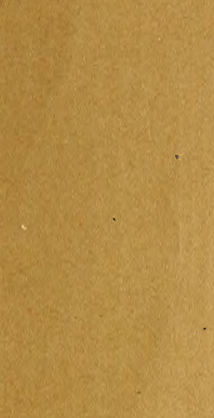

mase

$+2$

s.

tin 


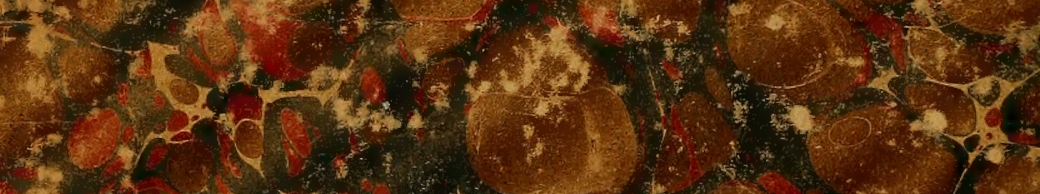
1.

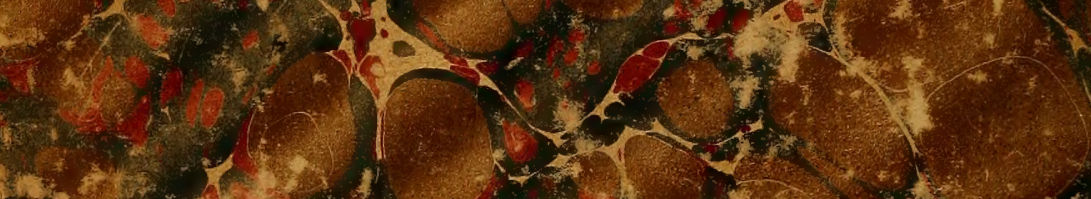

1.:-

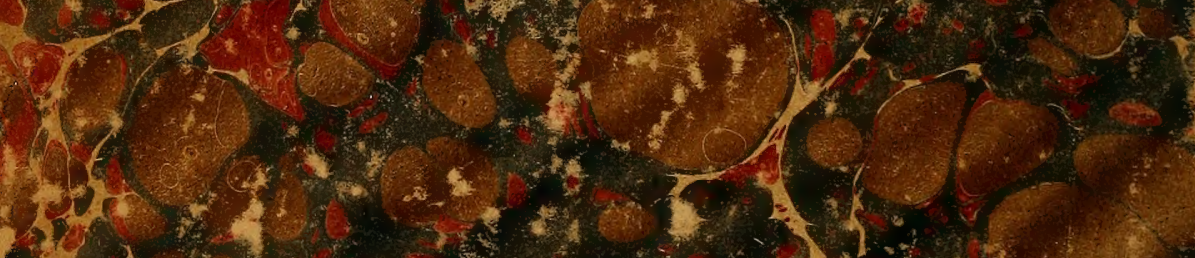

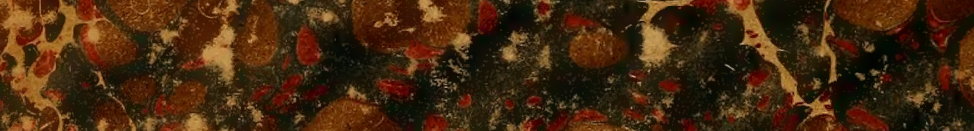

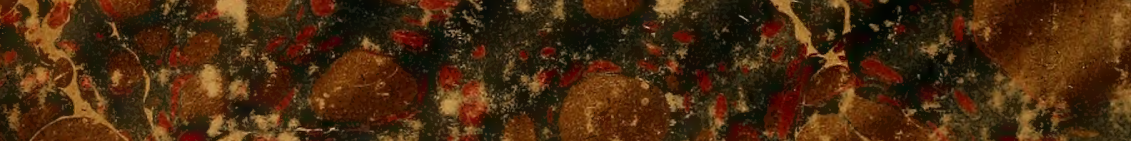

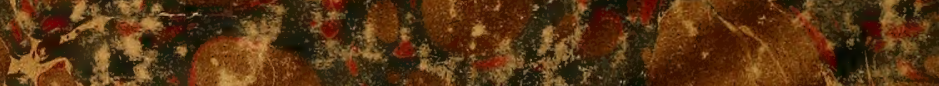
- 7 .

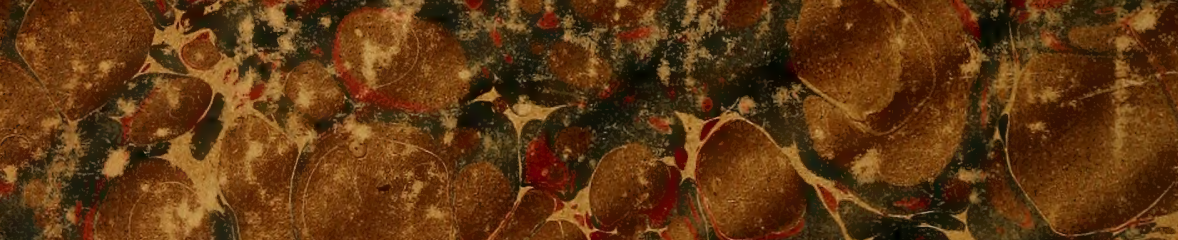

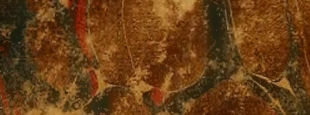

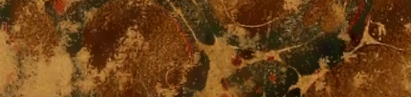

